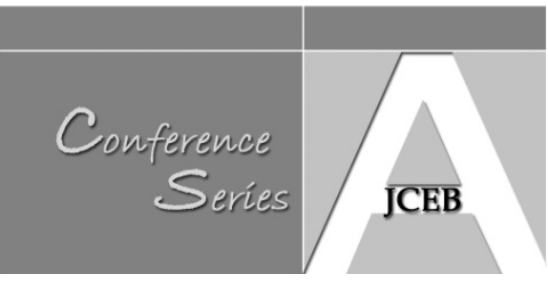

\title{
Adoption of Solar Grid-Tied PV-System Adopted in a Residential Building
}

Sun Wei and Egbelakin Temitope (Massey University, New Zealand)

\begin{abstract}
Emerging construction technologies focussing on the role and development of energyconserving equipment can play a major role in solving a wide range of environmental and nature resource problems such as the greenhouse gas. Alternative energy is becoming a popular for property developers because of its potential of becoming more economically viable option when compared to current energy source-electricity. The objective of this research report is to conduct a cost-benefit analysis of adopting a solar energy technology specifically the solar grid-tied system by comparing the cost of initial investment and usage in a typical three bedroom residential building a conventional electricity power supply. Using a case study research approach, the research findings showed that the PV system is more cost-effective in the long term compared to the conversional electricity supply. Although the pre-investment is relatively high in the PV system, it is a reliable investment in the long-term. It is important to emphasise that the use energy efficient appliances, lighting, insulation and double glassing has enhanced the effectiveness of the system.
\end{abstract}

Keywords: Photovoltaic system (PV); Solar energy; Cost-effectiveness

\section{Introduction}

Alternative energy technologies are becoming popular for property developers because of the potential economic benefits when compared to the current energy source-electricity (Kats and Capital, 2003). Several renewable energy technologies such as bio-fuels, biomass, solar panels, geothermal and wind turbine are now available in the market place. The benefits of solar energy as alternative source of power supply include providing a large proportion of a building's electricity supply, water heating requirements, minimal cost operation, reducing the use of electricity or fossil fuels and reducing energy cost (Chakrabarti and Chakrabarti, 2002). Olz et al. (2007) added that use of renewable technologies would increases the diversity in energy supply sources. Renewable energy technologies play major roles in solving several environmental and nature resource problems such as the greenhouse gas and resource conservation (Panwar et al., 2011). According to Dresselhaus and Thomas (2001), renewable energy technologies for generating electricity may generally be more energy efficient than non-renewable equivalent source.

Renewable energy plays an important role in New Zealand's energy supply system, with around $75 \%$ of electricity generated from renewable sources (Kelly, 2007). Solar energy represents one of the environmental friendliest ways of generating electricity with no significant impacts to the environment. New Zealand has good solar radiation levels in many locations with an average of 2000 hours of bright sunshine each year in New Zealand (Ministry of Commerce and Eden Resources, 1993). Historically, the main renewable sources in New Zealand have been hydro and geothermal energy. However, concern about climate change and limits on fossil fuel reserves, is driving the development and uptake of renewable energy technologies to generate electricity, provide heating and power 
machineries (Ghoniem, 2011). The invention and promotion of solar technology is making the power demand more close to energy self-sufficiency in New Zealand (Kelly, 2007). Several renewable technologies using solar energy is presently being used for generating electricity by means of photovoltaic panels for some residential building in New Zealand (Kelly, 2007). According to Boyle (2004) a solar house has proved to be more energy efficient than an equivalent conventional house built with the use of use "green" materials. However, a cost-benefit analysis has not yet been conducted on any of these emerging technologies for generating electricity in New Zealand. This study examined the cost-benefit analysis of adopting a solar energy technology such as the grid-tied photovoltaic solar system compared to conventional electricity supply in a typical three bedroom residential building in New Zealand. The next subsection provides a background on provides a background on the development and instalment of the photovoltaic solar system for residential buildings.

\section{Renewable Energy Technology - Photovoltaic Solar System (PV)}

Renewable energy systems such as the photovoltaic system would also reduce emissions of greenhouse gases (Vorobiev et al., 2006). The use of solar energy via the PV system helps to reduce greenhouse gas and has the potential to save cost of energy expense. A photovoltaic system (PV) transmits solar energy from the sun into its solar cells and converts the energy into electricity that can be used either within the structure or can be fed back into the electricity grid (Vorobiev et al., 2006). This system can be used both electricity supply and heating purposes. A typical Grid-tied PV system includes solar panels; inverter/charge controller interconnection wring and battery bank. Figure 1 shows the components and connections in a typical grid-tied photovoltaic system. Photovoltaic panels in a typical residential building are mounted using a grid-system.

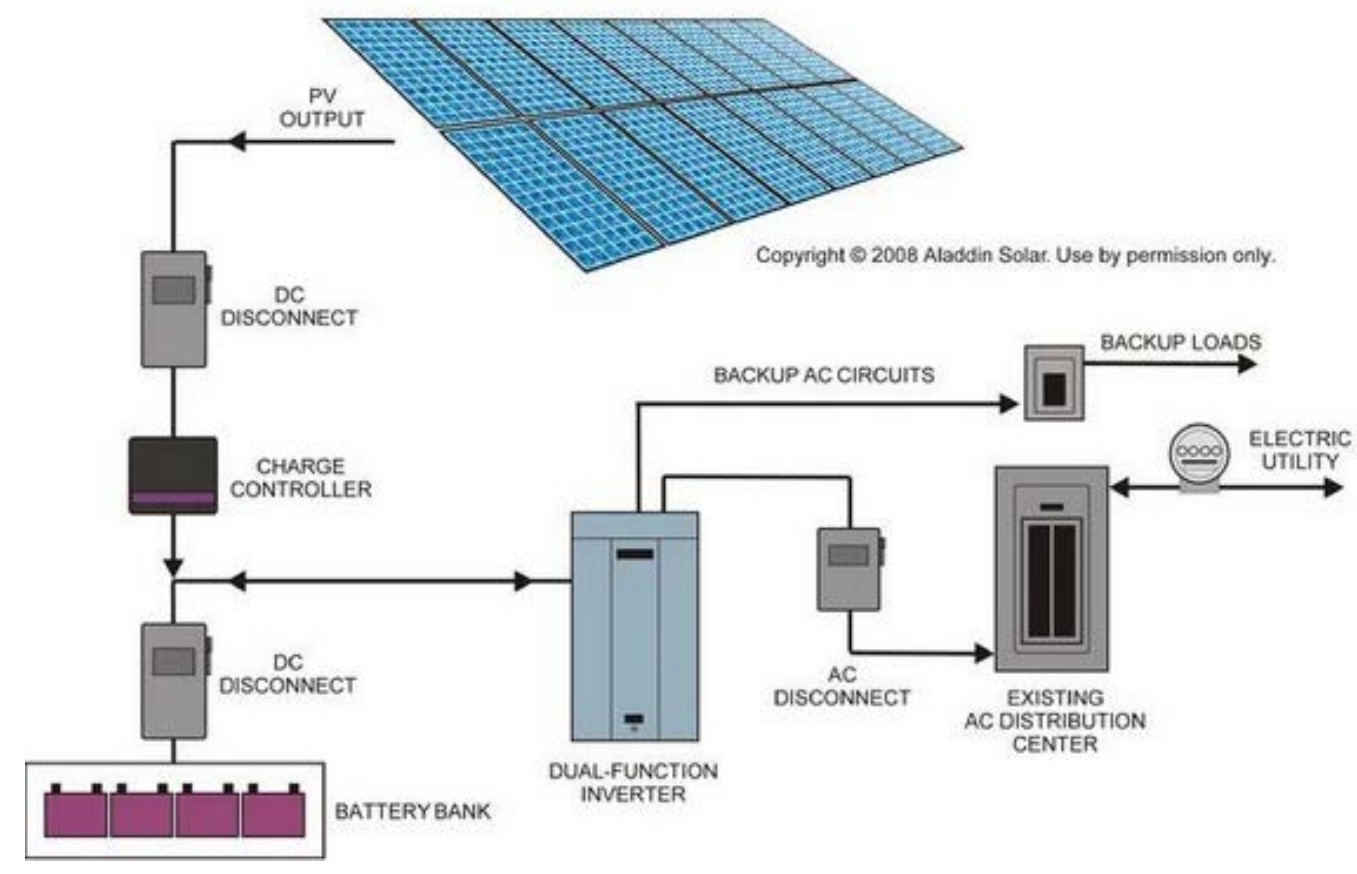

Figure 1. A typical PV Grid-Tied System with Battery Back-up (Source: Vorobiev et al., 2006)

Sun, W \& Egbelakin, T. 2014, 'Adoption of Solar Grid-Tied PV-System Adopted in a Residential Building', Australasian Journal of Construction Economics and Building, Conference Series, 2(2) 80-88. 
The dc electricity from the photovoltaic array is converted into mains-compatible ac by the grid-tied inverter, and the ac electricity is fed into the building's main electricity supply. Also, a cooling system may be installed to prevent overheating of the panels. Any excess electricity generated not used within the building is exported to the electrical supply grid. Further, the gird-tied PV system has no moving parts, is noiseless, produces no emissions during use and is completely scalable from small to large scale in a completely modular for expansion (Vogel and Kalb, 2010). All processing involved in the grid-connected systems has no identifiable effect on the environment (Vorobiev et al., 2006).

The initial cost of installation has been a challenge for adopting alternative energy technologies with no exception to the PV system. The cost of installing the PV system can vary depending on the size of the system, type of PV cells used, and whether the system is grid connected or has a battery unit to store surplus energy for later use (Kelly, 2007). A $10 K W$ system could cost about NZD100, 000 to $\$ 300,000$ (Kats and Capital, 2003). ARISE Technologies based in New Zealand supplies panels that have a 20 or 25 year warranty, depending on the type of cell. This warranty guarantees that the cells will produce at least $80 \%$ of original efficiency during the aforementioned 20 to 25 year period, while the cells have an expected life of 50 years (GB Report, 2006). Energy costs can be saved in a building if approximately $\$ 100 /$ year for a $10 \mathrm{KW}$ system can be produced within the building itself with additional savings during the pay-back periods. In addition, when electricity is generated and consumed within the same location, transmission and distribution losses are avoided and cost of wiring and maintenance is minimised, which reduces the utility's capital and maintenance costs (Vorobiev et al., 2006). The payback on solar heating systems ranges from 7 to 20 years depending on the cost of fuel displaced and the complexity of the system (Mills, 2004). Moreover, the cost of solar water heating system has dropped over the past 20 years, where the initial installation cost of commercial systems is about $\$ 500 / \mathrm{m}_{2}$ (Mills, 2004).

Periodic availability of solar energy is another challenge facing the adoption of alternative energy technologies. Most solar energy systems like the grid-tied PV system are limited by the amount of sunlight in a particular location and its orientation to the sunlight. A back-up and utility grid systems is required for storage and use of electricity during non-peak periods of sunlight (Vorobiev et al., 2006). The use of these additional systems is important because the peak electricity demand occur from $6 \mathrm{pm}$ to $8 \mathrm{pm}$, when solar energy is less available. In winter period, increased energy demand for water heating becomes less efficient due to lack of sunlight, making it difficult to meet the demand peak-period. The use of additional gas hot water heating and double glazing might help to resolve the peak-period energy demand (Mills, 2004). Increasing the battery's storage capacity may help to overcome the challenge of periodic availability of solar energy (Vorobiev et al., 2006). Despite this shortcoming, the design of a building and the use of certain equipment can in-directly improve the performance of a grid-tied PV system. Improving the efficiency of the PV system is possible through the use of energy efficient lighting, double glassing, heating and cooling systems, insulation materials and appliances with built-in power management features (Melaver and Mueller, 2009). Although, there is a growing perception within the construction industry regarding the use of PV system and these additional energy efficient technologies could increase construction costs (Yudelson, 2008). This study examines the adoption and costs of the PV system to that of a normal electricity supply in a typical three bedroom residential building.

Sun, W \& Egbelakin, T. 2014, 'Adoption of Solar Grid-Tied PV-System Adopted in a Residential Building', Australasian Journal of Construction Economics and Building, Conference Series, 2(2) 80-88. 


\section{Research Method}

A case study method was adopted in this study to examine the adoption and costeffectiveness of the grid-tied PV system. A case study method was adopted because of its usefulness in examining contemporary real-life phenomenon through detailed contextual analysis, while interviews and document analysis were used as data collection techniques (Yin, 2009). A single case study approach will be adopted in this study, using a residential house using grid-tied grid-tie photovoltaic solar system located in Auckland, New Zealand. Five visits to the house and the analysis to the relevant documents detailing the installation, operational, and maintenance of the system were examined. Face-to-face interviews were conducted with key personnel's involved the design, supervision and on-going management of the house, which allow in-depth understanding of the topic and allow the use of intensive probing questions to gain more insight into the research objective. A total of 12 interviews were conducted using an interview protocol, enabling clarification on any possible ambiguities and ensuring that all research areas have been fully discussed during the interview. The interviews ranged between one to two hours with majority taking a little more than an hour and are audio-taped. The recorded interviews were transcribed, which facilitated the content analysis of the discussions. Content analysis was adopted as the data analysis technique (Yin, 2009). Care was taken so that the information provided by the participants was transcribed accurately and the information validated by the participants in order to ensure reliability and validity of the results presented in subsequent section.

\section{Findings and Discussion}

The building used has a case study in this research is located in Meadow bank, bank, Auckland, New Zealand. The building was redesigned and rehabilitated for solar energy supply while maintaining near zero external sources of conventional energy for electricity supply and heating purposes. It is a modern $609 \mathrm{~m}^{2}$ property on prime north facing property which is necessary to maximum the solar energy supply to the property, with a $4.5 \mathrm{Kw}$ photovoltaic panel and wetback powering energy efficient application. The discussion in this section provide empirical evidence of the cost effectiveness of the PV system combined with other energy efficient systems adopted in the design, construction and materials used in the building.

\section{PV Panels and Solar Energy Hot Water System Installed on the Roof}

$250 \mathrm{~m}^{2}$ of solar panel modules were installed on the building roof. The panels are fixed with a simple aluminium channel, wired together in a series configuration of 15 modules each. The building was designed facing North with a roof slope of 20 degrees to the horizontal to allow maximum harvest of solar energy at peak period. These panels generate a total of $4.5 \mathrm{~kW}$ of electricity per peak sunshine hour. The cost of installing the PV panels is valued at over $\$ 60,000$ dollars, though this was considered a significant initial installation cost when compared to a conventional building with very minimal installation cost of approximately $\$ 300$ for wiring.

The installation of solar hot-water panels on the roof provided an all year supply of hot water for under-floor and ambient air heating, cooking and washing purposes, while the installation of radiator system allows the even distribution and control of the temperature in different rooms.

\section{Electricity Supply Back-up System}

A back-up system for electricity supply was designed and put-in place for emergency. The property owners adopted the first installation of NZ designed Whisper-Gen technology

Sun, W \& Egbelakin, T. 2014, 'Adoption of Solar Grid-Tied PV-System Adopted in a Residential Building', Australasian Journal of Construction Economics and Building, Conference Series, 2(2) 80-88. 
providing both additional electricity source and hot water heating during winter months when solar energy supply is relatively low. The electric back-up system during the winter months is boosted by wetback system and boiler. A condensing boiler preserves energy by using heat exchangers designed to remove additional energy from the gases of combustion before leaving the stack. The flue gases produced from condensing boilers are at a much lower temperatures than those of non-condensing boilers to the extent that the water vapour in the flue gases condenses, thus releasing their latent heat and increasing efficiency of the boiler. Condensing boilers have efficiencies of $95 \%$ or greater as compared to the normal $70 \%-80 \%$ for non-condensing boilers. The property owner mentioned that, solar hot water system would have given us an absolute abundance of hot-water in the summer months. Moreover, in practice this has not been an issue at all, as the back-up system has been absolutely wonderful in winter.

\section{Insulated Walls, Floors and Ceiling}

All external and internal walls, floors and ceilings were insulated with a high grade insulation material to minimise heating requirements. Also, all windows were double-glassed to reduce heat loss. The following assertions from the property owners emphasised the importance of using adequate insulation throughout the building.

- Installing insulation in the internal walls made perfect sense. The additional cost is minimal. Without insulation, 95\% of the heat generated within the house is lost through $35 \%$ via the roof, $25 \%$ via the walls, $10 \%$ through the floor, $10 \%$ out the single glazed windows and finally the last $15 \%$ out your doors.

- Insulating the house is the best thing to do for general health and wellbeing. The best $\$ 3000$ to $\$ 5000$ you ever spent.

- It is easier and cheaper to insulate during construction/renovation. Moreover, roof and under floor insulation usually a simple Saturday's job.

\section{Use Energy Efficient Lighting Systems and Appliances}

Energy efficient appliances and lighting are used throughout the house. The study findings found that about $20 \%$ of the current electricity bill comes from lighting which can be reduced by $1 / 6^{\text {th }}$, if energy saving lighting bulb is used. The illustration provided below accounted for how the use of the LED light bulbs will save a massive $\$ 36000$ dollar per annum in power bills.

For instance; using the 50,000 hours (approximately 34 years) of 100 Watt light in a building:

- Cost of using 50 incandescent light bulbs $=\$ 1088.50+\$ 64.00=\$ 1,152.50$

- Cost of using 8 compact fluorescents $=\$ 217.70+\$ 127.92=\$ 345.62$ cost (plus cost from potential mercury poisoning and environmental damage)

- $\quad$ Cost of using 1 EarthLED bulb@ \$141.51 + \$110.49=\$252

The illustration below was derived via the use of energy efficient light bulbs/lamps from Philips Lighting, which lasted for 8,000 - 12,000 hours of continuous use.

- A standard incandescent light bulb lasts for maximum of 1,000 hours. Hence, an extra 7,000 to 11,000 hours of bulb use before replacement. Therefore, convenience and economic benefits are achieved.

- Next, they use significantly less electricity to run. They generate light, rather than heat! A 9watt bulb will consume around 10 watts of energy per hour it's used. Therefore, the use of I bulb for $100 \mathrm{hours}$ will consume only $1 \mathrm{~kW}$ of power. In New Zealand, the cost of $1 \mathrm{~kW}$ of power is NZD\$0.12 cents. The incandescent light bulb is

Sun, W \& Egbelakin, T. 2014, 'Adoption of Solar Grid-Tied PV-System Adopted in a Residential Building', Australasian Journal of Construction Economics and Building, Conference Series, 2(2) 80-88. 
rated at about 60 watts, using approximately 16 hours of usage to consume 12 cents worth of electricity.

- The energy efficient compact fluoro bulb uses less than $1 / 6^{\text {th }}$ of the filament bulb power. This is a huge saving. The initial cost of the energy efficient bulb is $\$ 5$ dollars while the filament bulb cost about \$0.50c.

In addition, energy saving appliances were used throughout the building though these appliances were slightly more expensive than their counterparts. The property owner mentioned that; all of the bulbs lasted over 5years. This means continual usage of the bulbs will save energy and cost over the years, giving back to you the initial investment you made in them over and over again. Thus paying themselves off and putting money in your pocket over and over again.

\section{Cost Analysis of Power Bills}

The cost analysis data provided in Tables 1 and 2 demonstrated the cost-effectiveness of the PV solar system. The PV system provides $90 \%$ power needed in the house with an initial installation cost of 73000 NZD which including installation fee. On the average, the power bill amounts to an average of $\$ 50$ per month (see Table 1 ). The average power bill in Auckland is \$133-200 dollars per month for similar house types, using comparable equipment and appliances. The energy saving appliances used in this study helped to improve the performance of PV solar energy system. For instance, the 600 litres stainless steel hot water cylinder provides $90 \%$ heating power from PV system and $10 \%$ from backup system. Double glazing will avoid thermal loss and provides twice as effective as single glazing in terms of insulation, while heat recovery ventilation saves $75 \%$ of the energy produced. Overall, the PV system and energy saving equipment and appliances adopted in the house achieve an economic power bill which only 50 NZD per month for 609 square meter house.

Overall, the property used as a case in this study could be considered as an investment in a solar renewable energy technology. The property is also used a foundation for a lowmaintenance retirement home with minimal running and maintenance costs. Currently, the owners run daily tours through the house, and the energy features are tax-deductible because of its significance for publicity and marketing renewable energy technology. The solar energy house has achieved cost effectiveness through, design, energy efficient appliances and materials.

\section{Conclusion}

Solar radiation is an abundant energy source which is free, non-polluting, and renewable. New Zealand has good solar radiation levels in many locations, yet this energy source is vastly under-utilised. A case study method adopted in this study was used to examine the implementation and cost analysis of adopting a grid-tied photovoltaic (PV) solar system, compared to a conventional electricity supply in a typical three bedroom residential building in New Zealand. The research findings showed that the PV system is more cost-effective in the long term compared to the conversional electricity supply, though the pre-investment is higher. It is important to emphasise that the use energy efficient appliances, lighting, insulation and double glassing has enhanced the effectiveness of the system. Overall, New Zealand's electricity bills are generally higher than other countries such as China. The adoption of the PV systems is a good opportunity for the development of renewable energy in New Zealand if adequately supported by the government.

Sun, W \& Egbelakin, T. 2014, 'Adoption of Solar Grid-Tied PV-System Adopted in a Residential Building', Australasian Journal of Construction Economics and Building, Conference Series, 2(2) 80-88. 
Table 1. Energy Cost of the PV installed House

\begin{tabular}{|c|c|c|c|c|c|c|c|c|}
\hline \multicolumn{9}{|c|}{ Solar energy house in Meadowbank } \\
\hline Technology & Cost investment & Performances & Units & Service Units & Service period & Working life & Effect factor & \begin{tabular}{|l} 
Payback \\
Period
\end{tabular} \\
\hline \begin{tabular}{|l|} 
photovoltaic solar \\
electric modules
\end{tabular} & Over $\$ 60000$ & \multirow{4}{*}{$\begin{array}{c}\text { 4.5kw modules provide } 90 \% \\
\text { power need }\end{array}$} & \multirow{4}{*}{2 sets of 15 modules } & \multirow{4}{*}{$\begin{array}{l}2 \text { adults and } 3 \\
\text { children; } 7 \\
\text { computers, } 4 \text { staff }\end{array}$} & \multirow{4}{*}{$10-15$ years } & \multirow{4}{*}{50 years } & \multirow{4}{*}{$\begin{array}{l}\text { low effective } \\
\text { during cloudy }\end{array}$} & \multirow{4}{*}{$6-7$ years } \\
\hline Inverter & $\$ 3,000$ & & & & & & & \\
\hline Batteries & Over 35000 & & & & & & & \\
\hline Installation & $\$ 6,000$ & & & & & & & \\
\hline Solar water heating & Over $\$ 30000$ & $\begin{array}{c}600 \text { litre stainless steel hot water } \\
\text { cylinder; } 90 \% \text { power from solar, } \\
10 \% \text { from backup gas }\end{array}$ & $\begin{array}{c}4 \text { Israel-made Chromagen solar } \\
\text { heating collector; Total } 11.2 \text { square } \\
\text { metres }\end{array}$ & $\begin{array}{c}4 \text { badroon shower; } \\
\text { Space heating system }\end{array}$ & 15-20years & 50-60years & $\begin{array}{c}\text { low effective } \\
\text { during cloudy'; but } \\
\text { has backup system }\end{array}$ & 6-7 years \\
\hline Insulation & $\$ 3000-\$ 5000$ & $\begin{array}{c}\text { blocking every single hole; also } \\
\text { dampen noise transmitting from } \\
\text { one room to another } \\
\end{array}$ & Autex's greenstuf product & $\begin{array}{l}\text { Walls, Floor \& } \\
\quad \text { Ceiling }\end{array}$ & N/A & over 50years & Fire; damp & N/A \\
\hline Under floor heating & $\$ 3000-\$ 4000$ & $\begin{array}{l}\text { Save } \$ 50 \text { pre month but winter } \\
\text { only }\end{array}$ & $\begin{array}{l}\text { 3/8" diameter copper pipe on the } \\
\text { floor; } 18 \mathrm{~mm} \text { thick fibrolite on top }\end{array}$ & 3 of the 4 bathrooms & N/A & over 50years & N/A & $5-6$ years \\
\hline Space Heating & $\$ 3000-\$ 4000$ & $\begin{array}{c}\text { Solar hot-water flow pipe to warm } \\
\text { room; Booster backup }\end{array}$ & $\begin{array}{l}\text { through radiators to provide us with } \\
\text { space heating }\end{array}$ & Main room; lounge & $15-20$ years & 50-60years & $\begin{array}{c}\text { Cloudy but backup } \\
\text { system can get } \\
\text { over it just add } \\
\text { extra bill }\end{array}$ & 3-5years \\
\hline Double Glazing & Over $\$ 15000$ & Avoid thromal loss & $\begin{array}{c}\text { twice as effective as single glazing, } \\
\text { in terms of heat insulation }\end{array}$ & Windows and Doors & N/A & Over 50years & N/A & 5-10years \\
\hline $\begin{array}{l}\text { Heat Recovery } \\
\text { Ventilation }\end{array}$ & $\$ 4000-\$ 5000$ & $\begin{array}{l}\text { An HRV can save } 75 \% \text { or more } \\
\text { of wasted energy; As it pushes } \\
\text { out stale air, it pulls in fresh air }\end{array}$ & HRV products & $\begin{array}{c}\text { Bedrooms; } \\
\text { mainrooms; lounges }\end{array}$ & $\begin{array}{l}\text { Clean core and check fans; During } \\
\text { Check condensate drain } \\
\text { Check grilles and ducts in house } \\
\text { Reset dehumidistat ( } 40 \text { - } 80 \text { per cent) } \\
\text { During Sep or Oct }\end{array}$ & $15-20$ years & $\begin{array}{l}\text { Require maintain } \\
\text { on time }\end{array}$ & N/A \\
\hline $\begin{array}{l}\text { BAN the } \\
\text { incandescent light } \\
\text { Bulb }\end{array}$ & around $\$ 1800$ & $\begin{array}{l}\text { reliability and natural warm } \\
\text { colour effect }\end{array}$ & $\begin{array}{l}\text { Use compact Fluoro or New LED } \\
\text { light Bulb; Philips products }\end{array}$ & All the light & $x^{2}$ & 50000 hours & N/A & N/A \\
\hline Total & $\$ 200,000$ & & & & & & & \\
\hline
\end{tabular}

Sun, W \& Egbelakin, T. 2014, 'Adoption of Solar Grid-Tied PV-System Adopted in a Residential Building', Australasian Journal of Construction Economics and Building Conference Series, 2(2) 80-88. 
Table 2. Energy Cost in a Conventional Similar Building in Auckland

\begin{tabular}{|c|c|c|c|c|c|c|c|}
\hline \multicolumn{8}{|c|}{ Conventional building in Auckland } \\
\hline Techonlogy & $\begin{array}{c}\text { Achieve } \\
\text { equipment }\end{array}$ & Power Supply & Performances & Electricty/Gas Bills & Service Units & Service period & Working life \\
\hline Single Glazing & Simgle glazing & N/A & $\begin{array}{c}\text { Thromal loss; indirectly increasing } \\
\text { power supply }\end{array}$ & N/A & Windows \& Doors & N/A & Over 50years \\
\hline \multirow[t]{2}{*}{ Heating system } & Heater & Electricity & Individual heater; flexiable & $\$ 250-\$ 300$ & Individual room & N/A & 5-10years \\
\hline & $\begin{array}{l}\text { Gas Central } \\
\text { Heating }\end{array}$ & Gas & $\begin{array}{l}\text { using ventilation systems within the } \\
\text { ceiling; and temperature is } \\
\text { controlled by the switch board;The } \\
\text { boiler heat rooms, Room air is } \\
\text { absorbed through pipes to tank of } \\
\text { hot water, and warm air is supplied } \\
\text { to each room. }\end{array}$ & $\begin{array}{l}\$ 150-\$ 200 \text { pre } \\
\text { mounth }\end{array}$ & Worm house & 1-2year & 10years \\
\hline Cooling System & Air condistion & Electricity & \begin{tabular}{|c|} 
Add electricity bills \\
\end{tabular} & $\$ 50-\$ 100$ & lounge, office room & 2-3years & 10-15years \\
\hline \multirow[t]{2}{*}{ Hot water heating } & Gas hot water & Gas & $\begin{array}{l}\text { Fire heat cold water; hot water } \\
\text { through pipes to supply }\end{array}$ & $\$ 50-\$ 100$ per mounth & baths, showers, laundry and so on & 5years & 10-20years \\
\hline & $\begin{array}{l}\text { Electricity hot } \\
\text { water }\end{array}$ & Electricity & $\begin{array}{l}\text { Same as solar hotwater system, but } \\
\text { power is from electricity }\end{array}$ & $\$ 150-\$ 200$ & baths, showers, laundry and so on & 2-5years & 10-20years \\
\hline Insulation & $\begin{array}{c}\text { lots NZ home } \\
\text { have no } \\
\text { insulation } \\
\end{array}$ & N/A & $\begin{array}{l}\text { Thromal loss; indirectly increasing } \\
\text { power supply }\end{array}$ & N/A & Walls, Floor \& Ceiling & N/A & Over 50years \\
\hline Under floor heating & Cooper Pipes & Electricity & Worm badrooms floor & $\$ 50$ pre month & Badrooms & N/A & Over 50years \\
\hline $\begin{array}{l}\text { BAN the } \\
\text { incandescent light } \\
\text { Bulb } \\
\end{array}$ & 100W Bulbs & Electricity & $\begin{array}{l}\text { Save install cost, but more bills in } \\
\text { long term }\end{array}$ & $\$ 50-\$ 100$ per mounth & House & N/A & 8000-12000hours \\
\hline Others applications & $\begin{array}{c}\text { TV, Computers, } \\
\text { Fridger etc }\end{array}$ & Electricity & Daily life requirement & $\$ 100$ pre-month & House applications & N/A & N/A \\
\hline Total bills of power & $\$ 500-\$ 550$ & & & & & & \\
\hline
\end{tabular}

Sun, W \& Egbelakin, T. 2014, 'Adoption of Solar Grid-Tied PV-System Adopted in a Residential Building', Australasian Journal of Construction Economics and Building Conference Series, 2(2) 80-88. 


\section{References}

Boyle, G. 2004, Renewable Energy, Oxford University Press, UK.

Chakrabarti, S. \& Chakrabarti S. 2002, 'Rural Electrification Programme with Solar Energy in Remote Region-A Case Study in an Island', Energy Policy, 30 (1), 33-42

Dresselhaus, M. \& Thomas, I. 2001, 'Alternative Energy Technologies', Nature 414 (6861), 332-337.

Ghoniem, A. 2011, 'Needs, resources and climate change: clean and efficient conversion technologies', Progress in Energy and Combustion Science, 37(1), 15-51

Kats, G. and Capital, E. 2003, Green Building Costs and Financial Benefits, Massachusetts Technology Collaborative, Boston, MA.

Kelly, G. 2007, 'Renewable Energy Strategies in England, Australia and New Zealand,' Geoforum 38(2), 326-338

Mills, D. 2004, 'Advances in Solar Thermal Electricity Technology', Solar Energy 76(1), 19-31

Ministry of Commerce and Eden Resources 1993, Renewable Energy Opportunities for New Zealand: Executive Report, Ministry of Commerce and Eden Resources, Wellington, New Zealand.

Olz, S., R. Sims and N. Kirchner (2007). Contribution of Renewables to Energy Security IEA Information Paper, International Energy Agency (IEA).

Panwar, N., Kaushik, S. \& Kothari, S. 2011, 'Role of Renewable Energy Sources in Environmental Protection: A Review', Renewable and Sustainable Energy Reviews, 15(3), 1513-1524

Vorobiev, Y., Gonzalez-Hernandez, J., Vorobiev, P. et al. 2006, 'Thermal-photovoltaic Solar Hybrid System For Efficient Solar Energy Conversion', Solar Energy, 80(2), 170-176

Yin, R. K. 2009, Case Study Research: Design and Methods, Sage Publications, Los Angeles.

Yudelson, J. 2008, The Green Building Revolution, Island Press, Washington DC.

Sun, W \& Egbelakin, T. 2014, 'Adoption of Solar Grid-Tied PV-System Adopted in a Residential Building', Australasian Journal of Construction Economics and Building Conference Series, 2(2) 80-88. 